\title{
Removal of heavy metals from a contaminated soil using organic chelating acids
}

\author{
*R. A. Wuana; F. E. Okieimen; J. A. Imborvungu
}

Department of Chemistry, Benue State University, Makurdi, Nigeria

Received 17 Februray 2010; revised 25 March 2010; accepted 14 May 2010; availaEOHonline 1 June 2010

\begin{abstract}
Changes in heavy metal speciation and uptake by maize in a soil before and after washing with chelating organic acids, citric acid, tartaric acid and ethylenediaminetetraacetic acid were assessed. A sandy loam was collected from the vicinity of the Benue industrial layout, Makurdi, Nigeria and spiked with a quinternary mixture of nickel, copper, zinc, cadmium and lead nitrates to achieve higher levels of contamination. Batch soil washing experiments performed on $1.0 \mathrm{~g}$ portions of the spiked soil using $0.05 \mathrm{M}$ chelating agents at a solid:liquid ratio of 1:25 showed that washing efficiencies varied in the order: ethylenediaminetetraacetic acid> citric acid> tartaric acid with metal extraction yields typically following the sequence, copper $>$ nickel $>$ zinc $>$ cadmium $>$ lead. Sequential extractions proposed by the European Communities Bureau of Reference method used to assess the redistribution of heavy metal forms in the soil showed that apparent metal mobilities were reduced upon soil washing. Citric acid removed most of the metals hitherto associated with the exchangeable and reducible fractions; tartaric acid, the exchangeable metal pools; and ethylenediaminetetraacetic acid, the non-residual metal pools. Heavy metal assay of harvested biomass of maize grown on unwashed and washed soil samples indicated that metal transfer coefficients, decreased in the order of treatment: ethylenediaminetetraacetic acid $<$ citric acid $<$ tartaric acid < unwashed soil. Ethylenediaminetetraacetic acid and citric acid appeared to offer greater potentials as chelating agents to use in remediating the high permeability soil. Tartaric acid, however, is recommended in events of moderate contamination.
\end{abstract}

Keywords: Chemical speciation; Contaminated soil; Ethylenediaminetetraacetic acid; Plant uptake; Soil washing

\section{INTRODUCTION}

Heavy metal contamination of soil is one of the most important environmental problems throughout the world (Doumett et al., 2008; Nouri et al., 2006). The ability of heavy metals to accumulate and cause toxicity in biological systems - humans, animals, microorganisms and plants has been reported ( Nouri, 1980; D’amore et al., 2005). As chemical hazards, heavy metals are non-biodegradable and can remain almost indefinitely in the soil environment. However, their availability to biota can change considerably depending on their chemical speciation in the soil. The adequate protection and restoration of the soil ecosystems, therefore, require the characterization and remediation of soils that are contaminated with heavy metals (Nouri et al., 2008; Nwachukwu et al., 2010).

Remediation techniques include: (i) ex-situ (excavation) or in-situ (on-site) soil washing/leaching/

\footnotetext{
*Corresponding Author Email: raywuana@yahoo.com
} Tel./Fax: :+2348066645047 flushing with chemical agents, (ii) chemical immobilization/stabilization method to reduce the solubility of heavy metals by adding some non-toxic materials into the soils, (iii) electrokinetics (electromigration), (iv) covering the original polluted soil surface with clean soils, (v) dilution method (mixing polluted soils with surface and subsurface clean soils to reduce the concentration of heavy metals), (vi) phytoremediation by plants such as woody trees (GOC, 2003; Fawzy, 2008; Nouri et al., 2009; Kord et al., 2010).

Soil washing is particularly frequently used in soil remediation because it: (i) completely removes the contaminants, hence ensures the rapid cleanup of a contaminated site (Wood, 1997), (ii) meets specific criteria, (iii) reduces or eliminates long-term liability, (iv) may be the most cost-effective solution and (v) may produce recyclable material or energy (GOC, 2003). Since heavy metals are sparingly soluble and occur predominantly in a sorbed state, washing the soils with 
water alone is expected to remove too low an amount of cations in the leachates, chemical agents have to be added to the washing water (Davies and Singh, 1995; Dikinya and Areda, 2010). With chemical soil washing, soil particles are cleaned by selectively transferring the contaminants from the soil into solution (Nwuche and Ugoji, 2008). The effectiveness of washing is closely related to the ability of the extracting solution to dissolve the metal contaminants in soils. However, the strong bonds between the soil and metals make the cleaning process difficult. Therefore, only extractants capable of optimally dissolving the metals must be carefully sought during soil washing.

Several classes of chemicals used for soil washing include surfactants, cosolvents, cyclodextrins, chelating agents and organic acids (USEPA, 1990; Wood et al., 1990; Chu and Chan, 2003; Gao et al., 2003; Maturi and Reddy, 2008; Zhang et al., 2009; Zvinowanda et al., 2009). All these soil washing extractants have been developed on a case-by-case basis depending on the contaminant type at a particular site. A few studies have indicated that the solubilization/exchange/extraction of heavy metals by washing solutions differs considerably for different soil types. Strong acids attack and degrade the soil crystalline structure at extended contact times. For less damaging washes, organic acids and chelating agents are often suggested as alternatives to straight mineral acid use (Yu and Klarup, 1994).

Natural, low-molecular-weight organic acids including oxalic, citric, formic, acetic, malic, succinic, malonic, maleic, lactic, aconitic and fumaric acids are natural products of root exudates, microbial secretions and plant and animal residue decomposition in soils (Naidu and Harter, 1998). Thus metal dissolution by organic acids is likely to be more representative of a mobile metal fraction that is available to biota (Labanowski et al., 2008). The chelating organic acids are able to dislodge the exchangeable, carbonate and reducible fractions of heavy metals by washing procedures (Peters, 1999). Although many chelating compounds including citric acid (Naidu and Harter, 1998), tartaric acid (Ke et al., 2006) and EDTA (Tejowulan and Hendershot, 1998; Peters, 1999; Sun et al., 2001) for mobilizing heavy metals have been evaluated, there remain uncertainties as to the optimal choice for full-scale application. The identification and quantification of co-existing solid metal species in the soil before and after treatment are essential to design and assess the efficiency of soil washing technology (Kirpichtchikova et al., 2006). The objective of the present study was, therefore, to assess the potential of two natural, low molecular weight organic acids, citric acid (CA) and tartaric acid (TA); and an amino polycarboxylic acid, ethylenediaminetetraacetic acid (EDTA) to decontaminate a soil via soil washing experiments and study the changes in the redistribution of metal forms and bioavailability in the soil before and after washing using chemical speciation analysis and uptake by maize. The study was carried out on a composite soil sampled in the vicinity of the Benue Industrial Layout sited in Makurdi (a rapidly growing city located in the coordinates $7.44^{\circ} \mathrm{N}, 8.33^{\circ} \mathrm{E}$ in the Lower Benue River Basin, a major agricultural zone in Central Nigeria) from the months of June - July in 2009.

\section{MATERIALS AND METHODS}

\section{Chemicals and reagents}

Nickel (II) nitrate hexahydrate (98.5 w/w \%); copper (II) nitrate pentahydrate $(99.0 \mathrm{w} / \mathrm{w} \%)$; zinc nitrate hexahydrate $(99.0 \mathrm{w} / \mathrm{w} \%)$; cadmium nitrate tetrahydrate $(99.0 \%)$ and lead nitrate $(99.0 \mathrm{w} / \mathrm{w} \%)$ were used to spike soil sub-samples to simulate artificial contamination with $\mathrm{Ni}, \mathrm{Cu}, \mathrm{Zn}, \mathrm{Cd}$ and $\mathrm{Pb}$, respectively. Acetic acid (99.5 w/v \%), hydroxylamine hydrochloride $(99.0 \mathrm{w} / \mathrm{w} \%)$, ammonium acetate $(98.0 \mathrm{w} / \mathrm{w} \%)$, hydrogen peroxide (30\% w/v \%), hydrochloric acid (37 $\% \mathrm{w} / \mathrm{v} \%)$ and nitric acid ( $99.5 \% \mathrm{w} / \mathrm{v} \%)$ were used to prepare extracting solutions for sequential chemical fractionation as the case may be. Citric acid, $(99.5 \% \mathrm{w} /$ w\%); tartaric acid, (99.5 w/w \%) and ethylenediaminetetraacetic acid, EDTA $(99.0 \mathrm{w} / \mathrm{w} \%)$ were used to prepare solutions meant for soil washing. All reagents were of Fluka and Riedel-de Haën patent supplied by Sigma-Aldrich.

\section{Apparatus}

Normal laboratory glassware (borosilicate), polyethylene vessels, a $\mathrm{pH}$ meter, a multipurpose flask shaker (Model TT 12F, Techmel and Techmel, US) and a digitally operated high speed centrifuge (Model TGL$16 \mathrm{G})$ were used. A flame absorption spectrophotometer (Buck Scientific Model 200A) was used for metal assay.

\section{Soil sampling, spiking and characterization}

Surface soil $(0-15 \mathrm{~cm})$ samples were collected from an agricultural land in the vicinity of the Benue Industrial Layout using a chrome-plated trowel at five 
different locations. The soil samples were air-dried, ground and sieved to give $<2 \mathrm{~mm}$ particle size, bulked up to get a composite sample. The soil was spiked with a quinternary mixture of $\mathrm{Ni}, \mathrm{Cu}, \mathrm{Zn}, \mathrm{Cd}$ and $\mathrm{Pb}$ using aqueous solutions of their nitrates according to the methods of Reddy and Chinthamreddy (2000) with some modifications. $100 \mathrm{~mL}$ of $5000 \mathrm{mg} / \mathrm{L}$ of the quinternary metal stock was added to $1000 \mathrm{~g}$ of the air-dried parent soil (at a 10:1 solid:liquid ratio) and incubated for 4 weeks. The above spiking was intended to furnish about 500 $\mathrm{mg} / \mathrm{kg}$ as target concentration. The parent and amended soils were characterized in terms of physicochemical properties - $\mathrm{pH}$, textural analysis, soil organic matter, OM; cation exchange capacity and CEC (USEPA, 1995) and pseudototal $\mathrm{Ni}, \mathrm{Cu}, \mathrm{Zn}, \mathrm{Cd}$ and $\mathrm{Pb}$ content (Khodadoust et al., 2005).

\section{Soil washing experiments}

Batch extractions of heavy metal contaminants using a common extractant concentration of $0.05 \mathrm{M}$ were conducted according to the procedure reported by Khodadoust et al. (2005) with slight modifications using a soil:water ratio of 1:25 (i.e. $1 \mathrm{~g}$ of the soil with $25 \mathrm{~mL}$ of extracting solution). One gram of the parent soil spiked with quinternary mixture of $\mathrm{Ni}, \mathrm{Cu}, \mathrm{Zn}, \mathrm{Cd}$ and $\mathrm{Pb}$ was placed in a in 50-mL flask. Then, $25 \mathrm{~mL}$ of the extracting solution added and the flask was securely covered with a Teflon cork. Each flask was then shaken by hand for about a minute to ensure full saturation of the soil with solution and then the flasks were then shaken on a multipurpose flask shaker at $250 \mathrm{rpm}$ for $6 \mathrm{~h}$. The resulting soil - solution mixture was then centrifuged at $2000 \mathrm{rpm}$ for $10 \mathrm{~min}$. The supernatant was carefully decanted through a glass funnel impregnated with a filter paper and kept for heavy metal analysis as the case may be. The percent of each metal removed were calculated using an equation similar to the one earlier reported by Reddy and Chinthamreddy (2000) as:

Percent metal removed $(\%)=\frac{C_{l} V_{l}}{C_{s} m_{s}} \times 100$

Where $C_{1}$ and $C_{\mathrm{S}}$ are the concentrations of metal in supernatant (in $\mathrm{mg} / \mathrm{L}$ ) and soil $(\mathrm{mg} / \mathrm{kg})$, respectively; $V_{1}$ is the volume of supernatant (in L) and $m_{\mathrm{s}}$ is the dry mass of the soil (in $\mathrm{kg}$ ).

Metal distribution in soil before and afte decontamination

Sequential extractions proposed by the European Communities Bureau of Reference (BCR Method) were performed on 1-g portions of soil (oven-dried at $105^{\circ} \mathrm{C}$ for $2 \mathrm{~h}$ ) to assess the distribution of $\mathrm{Ni}, \mathrm{Cu}, \mathrm{Zn}, \mathrm{Cd}$ and $\mathrm{Pb}$ among operationally defined pools: extractable $\left(B_{1}\right)$, reducible $\left(B_{2}\right)$, organic-bound $\left(B_{3}\right)$ and in the soil before and after batch soil washing. The extractions were performed by shaking $1.0 \mathrm{~g}$ portion of the pretreated soil sample oven dried at $105{ }^{\circ} \mathrm{C}$ for $2 \mathrm{~h}$ in a mechanical shaker according to the steps described below (Ure et al., 1993; Tokalioglu et al., 2006; Golia et al., 2007) and summarized in Table 1.

Step $1\left(B_{1}\right): 40 \mathrm{~mL}$ of solution $0.11 \mathrm{M}$ acetic acid solution was added to $1.0 \mathrm{~g}$ of pretreated soil in a $100 \mathrm{~mL}$ centrifuge tube and extracted by shaking ( $30 \mathrm{rpm}$ ) for $16 \mathrm{~h}$ at ambient temperature (overnight). The extract was separated from the solid residue by centrifugation (at $1500 \mathrm{xg}$ ) and decantation of the supernatant liquid into a polyethylene container. The container was stoppered and stored at $4{ }^{\circ} \mathrm{C}$ prior to analysis. The residue was washed by adding $20 \mathrm{~mL}$ of distilled water, shaking for 15 mins and centrifuging. The supernatant was decanted and discarded, ensuring that no solid residue was discarded. The cake obtained upon centrifugation was broken by using a vibrating rod prior to the next step.

Step $2\left(B_{2}\right): 40 \mathrm{~mL}$ of $0.5 \mathrm{M}$ hydroxylamine hydrochloride solution was added to the residue from step 1 in the centrifuge tube and extracted by shaking for $16 \mathrm{~h}$ at ambient temperature (overnight). The extract was separated from the solid residue by centrifugation and decantation as in step 1 . The extract was retained in a stoppered polyethylene tube, as before, for analysis. The residue was washed by adding $20 \mathrm{~mL}$ of distilled water, shaking for $15 \mathrm{~min}$ and centrifuging. The supernatant was decanted and discarded taking care to avoid discarding any solid residue. The residue was retained for step 3. The cake obtained upon centrifugation was broken using a vibrating rod prior to the next step.

Step $3\left(B_{3}\right): 10 \mathrm{~mL}$ of $8.8 \mathrm{M}$ hydrogen peroxide solution was added carefully, in small aliquots to avoid losses due to violent reaction, to the residue in the centrifuge tube. The vessel was covered with a watch glass and digested at room temperature for $1 \mathrm{~h}$ with occasional manual shaking. The digestion was continued for $1 \mathrm{~h}$ at $85^{\circ} \mathrm{C}$ and the volume reduced to a few $\mathrm{mL}$ by further heating of the uncovered vessel on a water bath. A further $10 \mathrm{~mL}$ aliquot of the hydrogen peroxide solution 
was added and the covered vessel heated again to $85^{\circ} \mathrm{C}$ and digested for $1 \mathrm{~h}$. The cover was removed and the volume of the liquid reduced to a few $\mathrm{mL}$. Next, 50 $\mathrm{mL}$ of $1.0 \mathrm{M}$ ammonium acetate solution were added to the cool moist residue and shaken for $16 \mathrm{~h}$ at ambient temperature (overnight). The extract was separated from the solid residue by centrifugation and decantation in polyethylene tube as in step 1 and 2 stoppered and retained as before for analysis.

Residual $\left(R_{4}\right)$ : Aqua regia digestion was employed in the extraction of the residual fraction. That is, $21 \mathrm{~mL}$ of conc. $\mathrm{HCl}$ and $7 \mathrm{~mL}$ concentration $\mathrm{HNO}_{3}$ were added to the residue from step 3 and digested at $180^{\circ} \mathrm{C}$ overnight (in a fume chamber). The digest was kept for metal assay.

Impact of soil washing on heavy metal uptake by maize

Portions $(1 \mathrm{~kg})$ of sub-sample of the parent soil spiked with quinternary mixture of $\mathrm{Ni}, \mathrm{Cu}, \mathrm{Zn}, \mathrm{Cd}$ and $\mathrm{Pb}$ nitrates were separately transferred to $2-\mathrm{L}$ vessels. Aliquots of $0.05 \mathrm{M}$ solutions each of CA, TA and EDTA were added at a soil:solution ratio of 1:25 and soils washed at a contact time of $6 \mathrm{~h}$. The supernatants were decanted, the residue dried and kept as washed soil. Pot experiments adopted the procedures of Nolan et al. (2005) and Battaglia et al. (2006). The above ground plant biomass was harvested after 35 days of growth and the concentrations of $\mathrm{Ni}, \mathrm{Cu}, \mathrm{Zn}, \mathrm{Cd}$ and $\mathrm{Pb}(\mathrm{mg} / \mathrm{kg}$ dry weight of plant biomass) were determined by atomic absorption spectrophotometer (AAS) after $\mathrm{HNO}_{3}-\mathrm{H}_{2} \mathrm{O}_{2}$ digestion.

\section{RESULTS AND DISCUSSION}

Physicochemical properties of soil

Some physicochemical properties of the parent and metal-spiked soils are reported in Table 2. Preliminary visual inspection showed that the soil was dark grey in colour indicating a low amount of humus. Colour is one of the characteristics of soil, which tells much about the origin of the soil and its composition. The soil is derived from Precambrian basement complex rocks and quaternary alluvial deposits of the River Benue as parent materials (Okezie, 1985). Textural analysis showed the preponderance of sand fraction

Table 1: BCR sequential extraction procedure used for heavy metal speciation

\begin{tabular}{llll}
\hline Step & Metal pools & Extractant & Agitation time \\
\hline$B_{1}$ & Extractable & $40 \mathrm{~mL}$ of $0.11 \mathrm{M} \mathrm{CH}_{3} \mathrm{COOH}$ & $16 \mathrm{~h}$ at room temperature \\
$B_{2}$ & Reducible & $40 \mathrm{~mL}$ of $0.5 \mathrm{M} \mathrm{NH} \mathrm{OH}_{2} \mathrm{HCl}(\mathrm{pH} 2)$ & $16 \mathrm{~h}$ at room temperature \\
$B_{3}$ & Organic-bound & $10 \mathrm{~mL}$ of $8.8 \mathrm{M} \mathrm{H}_{2} \mathrm{O}_{2}$ & $1 \mathrm{~h}$ at room temperature \\
& & $\mathrm{Cool}+50 \mathrm{~mL}$ of $1 \mathrm{M} \mathrm{CH}_{3} \mathrm{COONH}_{4} \mathrm{~h}$ at $85^{\circ} \mathrm{C}$ \\
& & $(\mathrm{pH} 2)$ & $16 \mathrm{~h}$ at room temperature \\
$R_{4}$ & Residual & Aqua regia digestion $\left(21 \mathrm{~mL}^{\circ}\right.$ concentration $\mathrm{HCl}$ & $16 \mathrm{~h}$ at $180^{\circ} \mathrm{C}$ \\
& & $+7 \mathrm{~mL}$ concentration $\left.\mathrm{HNO}_{3}\right)$ & \\
\hline
\end{tabular}

Ure et al. (1993); Tokalioglu et al. (2006); Golia et al. (2007)

Table 2: Some physicochemical properties and pseudototal heavy metal content of the parent soil and soil spiked with heavy metals in form of their nitrates

\begin{tabular}{|c|c|c|}
\hline Property & Parent soil & Spiked soil \\
\hline$p \mathrm{H}\left(\mathrm{H}_{2} \mathrm{O}\right)$ & $6.05 \pm 0.01$ & $7.15 \pm 1.15$ \\
\hline Particle size distribution (\%): Sand & $78.20 \pm 1.10$ & - \\
\hline Silt & $13.20 \pm 1.70$ & - \\
\hline Clay & $8.60 \pm 1.25$ & - \\
\hline Organic matter $(\%)$ : & $8.70 \pm 0.10$ & - \\
\hline Cation exchange capacity, CEC (\%) & $1.64 \pm 0.30$ & - \\
\hline \multicolumn{3}{|l|}{ Pseudototal metal content, $Q_{\mathrm{T}}(\mathrm{mg} / \mathrm{kg})$} \\
\hline & $0.18 \pm 0.90$ & $437.50 \pm 3.56$ \\
\hline & $1.20 \pm 0.10$ & $498.00 \pm 3.25$ \\
\hline & $1.50 \pm 1.10$ & $375.90 \pm 1.74$ \\
\hline & $0.34 \pm 0.30$ & $340.00 \pm 1.89$ \\
\hline & $1.30 \pm 1.10$ & $292.50 \pm 2.35$ \\
\hline
\end{tabular}


(78.20\%), followed by silt (13.20\%), then clay $(8.60 \%)$, thus classifying the parent soil as loamy sand (Soil survey staff, 1998). Sandy soils are known to have a poor retention capacity for both water and metals. The slightly acidic $\mathrm{pH} 6.05$ recorded for the parent soil is within the range of agricultural soils. Soil $\mathrm{pH}$ plays a major function in the sorption of heavy metals as it directly controls the solubility and hydrolysis of metal hydroxides, carbonates and phosphates. It also influences ion - pair formation, solubility of organic matter, as well as surface charge of $\mathrm{Fe}, \mathrm{Mn}$ and $\mathrm{Al}-$ oxides, organic matter and clay edges (Tokalioglu et al., 2006). The soil had low OM content (8.70\%) and CEC $(1.64 \%)$. The CEC parameter particularly measures the ability of soils to allow for easy exchange of cations between its surface and solution. The relatively low levels of silt, clay, OM and CEC indicate the high permeability, hence leachability of heavy metals in the soil and suggest that it might be amenable to remediation by soil washing (Ehsan et al., 2006; Atafar et al., 2010). Preliminary characterization also revealed very low heavy metal concentrations. Consequently, it was fortified with a quinternary mixture of heavy metal nitrates to achieve higher levels of $\mathrm{Ni}, \mathrm{Cu}, \mathrm{Zn}, \mathrm{Cd}$ and $\mathrm{Pb}$.
Heavy metal removal from soil by chelating organic acids

A common chelant concentration of $0.05 \mathrm{M}(50$ $\mathrm{mM}$ ) was employed in all soil washing experiments because the presence of these organic acids particularly citrate or tartrate at very low concentrations is found to inhibit the desorption of heavy metals, whereas their presence at high concentrations promotes metal desorption (Gao et al., 2003). Furthermore, Tejuwulan and Hendershot (1998) found that the rate of metal removal with EDTA depended only on the chelant concentration and not washing time. Consequently, a common washing time of $6 \mathrm{~h}$ was chosen since complexation of these divalent metal ions by chelants is found to be almost instantaneous (Chao et al., 1998). The chosen chelant concentration was also meant to maintain the $\mathrm{pH}$ of the soil-chelant mixture low enough for $\mathrm{Ni}$, $\mathrm{Cu}, \mathrm{Zn}, \mathrm{Cd}$ and $\mathrm{Pb}$ to exist as ions (Reddy and Chinthamreddy, 2000). The results of the 6-h batch washing of heavy metals from the contaminated soil with $0.05 \mathrm{M} \mathrm{CA}$, TA and EDTA are presented in Table 3 and Fig. 1.

Table 3: Chelant removal of heavy metals $(\mathrm{mg} / \mathrm{kg})$ and standard deviations $(n=3)$ from soil contaminated by spiking with metal nitrates

\begin{tabular}{lrrr}
\hline Metal & \multicolumn{1}{c}{ CA } & TA & EDTA \\
\hline $\mathrm{Ni}$ & $199.70 \pm 0.45$ & $123.80 \pm 1.22$ & $273.50 \pm 0.39$ \\
$\mathrm{Cu}$ & $250.50 \pm 2.10$ & $150.20 \pm 1.00$ & $350.40 \pm 0.50$ \\
$\mathrm{Zn}$ & $163.70 \pm 0.65$ & $100.00 \pm 0.35$ & $227.00 \pm 0.00$ \\
$\mathrm{Cd}$ & $130.60 \pm 1.70$ & $65.70 \pm 2.00$ & $192.8 \pm 2.25$ \\
$\mathrm{~Pb}$ & $90.80 \pm 0.90$ & $48.00 \pm 0.05$ & $147.70 \pm 1.29$ \\
\hline
\end{tabular}

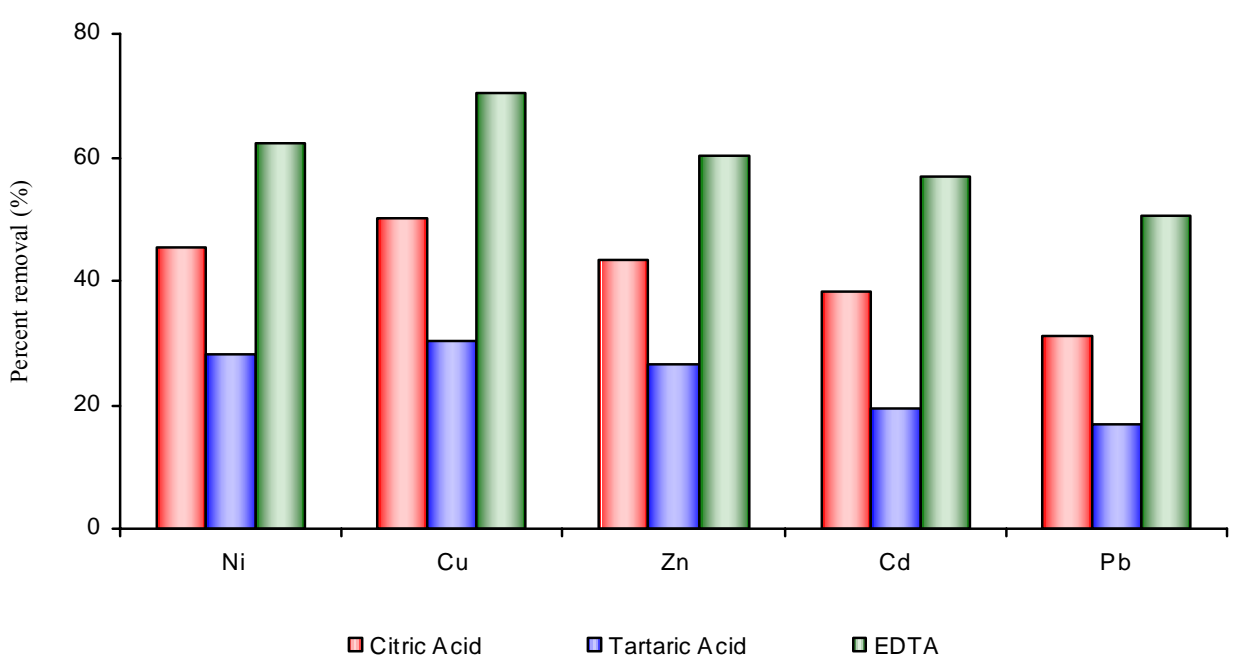

Fig. 1: Percent removal of heavy metals with various chelants from soil contaminated by spiking with metal nitrates 
The concentrations of extractable heavy metals and extraction yields varied considerably with the nature of organic chelant. At the end of the 6-h washing time, CA removed $45.60 \% \mathrm{Ni}, 50.30 \% \mathrm{Cu}, 43.50 \% \mathrm{Zn}, 38.40 \% \mathrm{Cd}$ and $31.00 \% \mathrm{~Pb}$. TA gave extraction yields of $28.30 \% \mathrm{Ni}$, $30.20 \% \mathrm{Cu}, 26.60 \% \mathrm{Zn}, 19.30 \% \mathrm{Cd}$ and $16.70 \% \mathrm{~Pb}$. The extraction yields of EDTA were $62.50 \% \mathrm{Ni}, 70.30 \% \mathrm{Cu}$, $60.40 \% \mathrm{Zn}, 56.70 \% \mathrm{Cd}$, and $50.50 \% \mathrm{~Pb}$. For all three organic chelants, extraction yields varied in the order: $\mathrm{Cu}>\mathrm{Ni}>\mathrm{Zn}>\mathrm{Cd}>\mathrm{Pb}$; approximately obeying the order of their formation constants, $\log K_{\mathrm{f}}$ at $0.01 \mathrm{M}$ ionic strength (Norvell, 1991). In spite of the intermediate value of formation constants for $\mathrm{Pb}$, the three chelants showed the least extraction yields for the former possibly due to its strong association with the residual soil fraction. Among the different chelants, extraction yields for all the five metals, varied in the order: EDTA $>$ CA $>$ TA. This observation is explicable by the fact that chelate effect increases in the order written. This effect is found to confer extra stability on chelates and largely originates from an increase in entropy resulting from an increase in the number of free molecules, usually solvent or other species, liberated as the chelate is formed. The size and number of rings, substituents on the rings and the nature of the metal and donor atoms are among the other factors that can affect the thermodynamic stability of these chelate systems (Chao et al., 1998). In the case of EDTA, its superlative extraction yields is further explicable by its ability to: (i) complex any metals in the soil solution (though with a different degree of selectivity for the different metals); (ii) desorb and complex loosely held metal ions and some more tightly held forms; and (iii) dissolve some minerals containing trace metals and complex the freed metals. In summary, the results of batch tests indicate that the chelant solutions removed $\mathrm{Ni}, \mathrm{Cu}, \mathrm{Zn}, \mathrm{Cd}$ and $\mathrm{Pb}$ simultaneously. A possible mechanism of metal extraction might have involved the initial dissolution of solid metal pools, leading to an initial high concentration of the target metal, $M$ and other competing cations, $M^{1}$ and then followed by ligand exchange reactions between $M$ and $M^{1}$. In practice, during chelant extraction of a target metal, it is intended that a recoverable chelant with enough strength to overcome all kinds of reactions in soils to form a stable complex and also likely to extract less competing ambient metals from soils be chosen. EDTA and CA appeared to offer the greatest potential as chelating agents to use in remediating this high permeability soil. TA can, however, be recommended in events of moderate contamination.

\section{Heavy metal redistribution in soil before and after washing}

In order to assess the efficacy of chelant extractions, the redistribution patterns of $\mathrm{Ni}, \mathrm{Cu}, \mathrm{Zn}, \mathrm{Cu}$ and $\mathrm{Pb}$ were determined using the BCR sequential extraction procedure to achieve heavy metal fractionation in soil, before and after CA, TA and EDTA extraction (Tables 4 -7 , Figs. $2 \mathrm{a}-2 \mathrm{~d})$.

Table 4: Pseudototal and BCR extracted metal concentrations $(\mathrm{mg} / \mathrm{kg})$ and standard deviations $(n=3)$ in soil contaminated by spiking with metal nitrates

\begin{tabular}{|c|c|c|c|c|c|}
\hline Fraction & $\mathrm{Ni}$ & $\mathrm{Cu}$ & $\mathrm{Zn}$ & $\mathrm{Cd}$ & $\mathrm{Pb}$ \\
\hline$\overline{B_{1}}$ & $63.30 \pm 1.00$ & $80.40 \pm 4.60$ & $95.30 \pm 1.20$ & $60.50 \pm 1.60$ & $40.10 \pm 0.60$ \\
\hline$B_{2}$ & $90.20 \pm 1.00$ & $73.00 \pm 1.20$ & $55.30 \pm 2.00$ & $60.00 \pm 1.90$ & $49.50 \pm 1.10$ \\
\hline$B_{3}$ & $120.30 \pm 2.10$ & $148.40 \pm 1.50$ & $90.10 \pm 2.20$ & $90.20 \pm 1.10$ & $64.00 \pm 2.20$ \\
\hline$\Sigma$ & $426.80 \pm 2.35$ & $476.80 \pm 2.00$ & $368.70 \pm 3.15$ & $329.70 \pm 3.70$ & $287.70 \pm 2.87$ \\
\hline Pseudo total & $437.50 \pm 3.56$ & $498.00 \pm 3.25$ & $375.90 \pm 1.74$ & $340.00 \pm 1.89$ & $292.50 \pm 2.35$ \\
\hline Recovery & 97.60 & 95.70 & 98.10 & 97.00 & 98.40 \\
\hline
\end{tabular}

Table 5: Pseudototal and BCR extracted metal concentrations $(\mathrm{mg} / \mathrm{kg})$ and standard deviations $(n=3)$ after citric acid washing of soil contaminated by spiking with metal nitrates

\begin{tabular}{|c|c|c|c|c|c|}
\hline Fraction & $\mathrm{Ni}$ & $\mathrm{Cu}$ & $\mathrm{Zn}$ & $\mathrm{Cd}$ & $\mathrm{Pb}$ \\
\hline$B_{1}$ & - & $3.40 \pm 1.70$ & $0.30 \pm 1.20$ & $2.50 \pm 1.60$ & - \\
\hline$B_{2}$ & - & $23.00 \pm 0.20$ & $5.30 \pm 1.00$ & $10.00 \pm 1.90$ & - \\
\hline$B_{3}$ & $110.30 \pm 1.10$ & $60.40 \pm 1.50$ & $90.10 \pm 1.50$ & $80.20 \pm 1.10$ & $20.00 \pm 1.20$ \\
\hline$R$ & $150.00 \pm 0.90$ & $160.50 \pm 2.50$ & $120.00 \pm 1.50$ & $110.00 \pm 2.00$ & $170.10 \pm 2.10$ \\
\hline$\Sigma$ & $260.30 \pm 1.30$ & $243.90 \pm 2.00$ & $215.40 \pm 1.15$ & $202.70 \pm 1.70$ & $190.10 \pm 2.80$ \\
\hline Pseudo total & $270.00 \pm 1.50$ & $250.00 \pm 2.30$ & $220.20 \pm 1.20$ & $209.40 \pm 1.85$ & $201.70 \pm 1.30$ \\
\hline Recovery 96.40 & 97.60 & 97.80 & 96.80 & 94.20 & \\
\hline
\end{tabular}


Int. J. Environ. Sci. Tech., 7 (3), 485-496, Summer 2010

Table 6: Pseudototal and BCR extracted metal concentrations $(\mathrm{mg} / \mathrm{kg})$ and standard deviations $(n=3)$ after tartaric acid washing of soil contaminated by spiking with metal nitrates

\begin{tabular}{lcrrrr}
\hline Fraction & \multicolumn{1}{c}{$\mathrm{Ni}$} & $\mathrm{Cu}$ & \multicolumn{1}{c}{$\mathrm{Zn}$} & \multicolumn{1}{c}{$\mathrm{Cd}$} \\
\hline$B_{1}$ & - & $10.40 \pm 0.60$ & - & - & $\mathrm{Pb}$ \\
$B_{2}$ & $29.70 \pm 1.20$ & $73.00 \pm 1.25$ & $60.30 \pm 1.30$ & $60.00 \pm 0.90$ & $40.60 \pm 1.30$ \\
$B_{3}$ & $110.30 \pm 1.10$ & $70.40 \pm 1.50$ & $40.10 \pm 2.40$ & $60.20 \pm 1.10$ & $30.00 \pm 1.25$ \\
$R$ & $163.00 \pm 1.15$ & $165.00 \pm 2.50$ & $148.00 \pm 1.85$ & $149.00 \pm 2.00$ & $169.10 \pm 2.10$ \\
$\Sigma$ & $303.00 \pm 2.00$ & $318.80 \pm 2.75$ & $248.40 \pm 2.15$ & $269.20 \pm 2.70$ & $239.70 \pm 2.85$ \\
Pseudo total & $313.70 \pm 1.50$ & $347.80 \pm 3.45$ & $275.00 \pm 1.90$ & $274.30 \pm 1.55$ & $244.50 \pm 2.05$ \\
Recovery & 96.60 & 91.70 & 90.30 & 98.10 & 98.00 \\
\hline
\end{tabular}

Table 7: Pseudototal and BCR extracted metal concentrations $(\mathrm{mg} / \mathrm{kg})$ and standard deviations $(n=3)$ after EDTA washing of soil contaminated by spiking with metal nitrates

\begin{tabular}{lcrrrr}
\hline Fraction & $\mathrm{Ni}$ & $\mathrm{Cu}$ & $\mathrm{Zn}$ & $\mathrm{Cd}$ & - \\
\hline$B_{1}$ & - & - & - & $5.30 \pm 0.05$ & - \\
$B_{2}$ & - & - & $10.10 \pm 0.10$ & $20.20 \pm 0.55$ & - \\
$B_{3}$ & - & $175.00 \pm 2.00$ & $133.00 \pm 2.80$ & $120.00 \pm 2.00$ & $10.00 \pm 0.75$ \\
$R$ & $158.00 \pm 1.30$ & $175.50 \pm 1.90$ & $148.40 \pm 2.05$ & $140.20 \pm 1.70$ & $287.70 \pm 1.87$ \\
$\Sigma$ & $158.00 \pm 2.15$ & $180.00 \pm 1.25$ & $150.50 \pm 1.70$ & $145.00 \pm 1.50$ & $140.50 \pm 1.30$ \\
Pseudototal & $164.00 \pm 2.50$ & 97.00 & 98.60 & 96.70 & 99.60 \\
Recovery & 96.30 & & & & \\
\hline
\end{tabular}

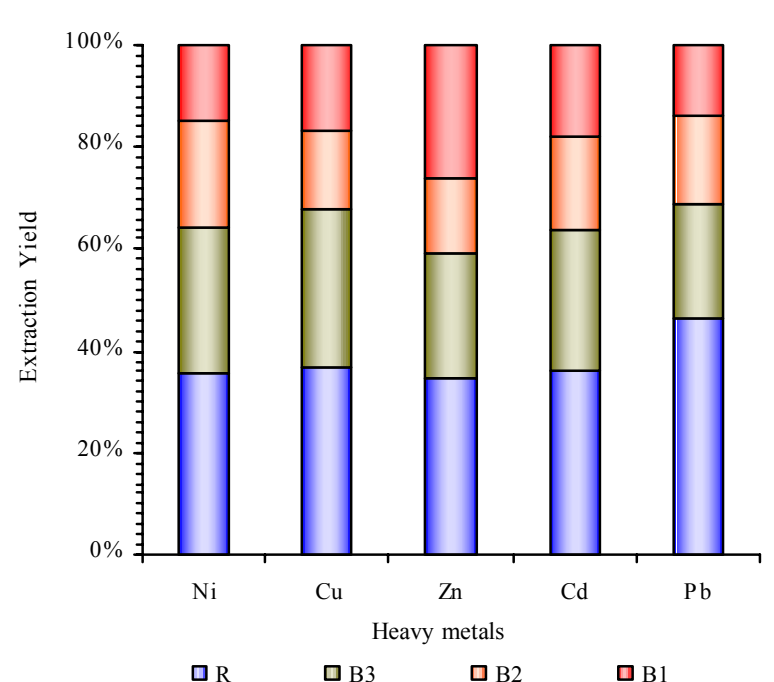

Fig. 2a: Heavy metal distribution in unwashed soil determined by the BCR sequential procedure $\left(B_{1}-\mathrm{CH}_{3} \mathrm{COOH} ; \mathrm{B}_{2}-\right.$ $\mathrm{NH}_{2} \mathrm{OH}-\mathrm{HCl}, \mathrm{pH} 1.5 ; \mathrm{B}_{3}-\mathrm{H}_{2} \mathrm{O}_{2}$ then $\mathrm{CH}_{3} \mathrm{COONH}_{4}, \mathrm{pH}$ 2 and $R_{4}$-aqua regia)

\section{Unwashed soil}

Pseudototal metal concentrations in the soil spiked with quinternary metal mixture were: $437.50 \mathrm{mg} / \mathrm{kgNi}$, $498.00 \mathrm{mg} / \mathrm{kg} \mathrm{Cu}, 375.90 \mathrm{mg} / \mathrm{kgZn}, 340.00 \mathrm{mg} / \mathrm{kgCd}$ and $292.50 \mathrm{mg} / \mathrm{kg} \mathrm{Pb}$ (Table 4). The foregoing data indicates that the levels of the heavy metals in parent soil were elevated following spiking operations. Mean

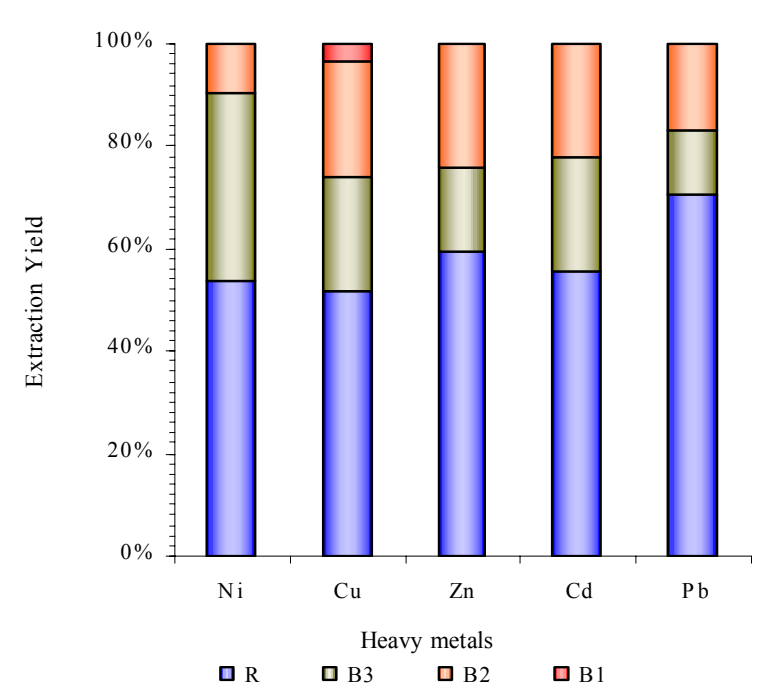

Fig. 2b: Heavy metal distribution in contaminated soil after washing with citric acid determined by the $\mathrm{BCR}$ sequential procedure $\left(B_{1}-\mathrm{CH}_{3} \mathrm{COOH} ; \mathrm{B}_{2}-\mathrm{NH}_{2} \mathrm{OH}-\mathrm{HCl}\right.$, $\mathrm{pH} 1.5 ; \mathrm{B}_{3}-\mathrm{H}_{2} \mathrm{O}_{2}$ then $\mathrm{CH}_{3} \mathrm{COONH}_{4}, \mathrm{pH} 2$ and $R_{4}$-aqua regia)

metal concentrations in the exchangeable fraction, $B_{1}$, were $63.30 \mathrm{mg} / \mathrm{kgNi}, 80.00 \mathrm{mg} / \mathrm{kgCu}, 85.30 \mathrm{mg} / \mathrm{kgZn}$, $60.50 \mathrm{mg} / \mathrm{kg} \mathrm{Cd}$ and $40.10 \mathrm{mg} / \mathrm{kg} \mathrm{Pb}$. These were equivalent to approximate extraction yields of $15 \% \mathrm{Ni}$, $17 \% \mathrm{Cu}, 26 \% \mathrm{Zn}, 18 \% \mathrm{Cd}$ and $14 \% \mathrm{~Pb}$ (Fig. 2a). Metal concentrations in the reducible fraction were: 90.20 $\mathrm{mg} / \mathrm{kg} \mathrm{Ni}, 73.00 \mathrm{mg} / \mathrm{kgCu}, 55.30 \mathrm{mg} / \mathrm{kgZn}, 60.00 \mathrm{mg} / \mathrm{kg}$ 
$\mathrm{Cd}$ and $49.50 \mathrm{mg} / \mathrm{kg} \mathrm{Pb}$; corresponding to extraction yields of $21 \% \mathrm{Ni}, 15 \% \mathrm{Cu}, 15 \% \mathrm{Zn}, 18 \% \mathrm{Cd}$ and $17 \%$ $\mathrm{Pb}$. This meant that comparatively, extraction yields in this fraction varied in the sequence $\mathrm{Ni}>\mathrm{Cd} \sim \mathrm{Pb}>\mathrm{Cu}$ $\sim$ Zn. Approximately, $36 \% \mathrm{Ni}, 32 \% \mathrm{Cu}, 41 \% \mathrm{Zn}, 45 \%$ $\mathrm{Cd}$ and $39 \% \mathrm{~Pb}$ in this soil can be said to be amenable to soil washing since they constitute the sum, $B_{1}+B_{2}$; i.e. exchangeable + carbonate + reducible oxides (Peters, 1999). Extraction yields in the organic matter fraction were $28 \% \mathrm{Ni}, 31 \% \mathrm{Cu}, 24 \% \mathrm{Zn}, 27 \% \mathrm{Cd}$ and $22 \% \mathrm{~Pb}$. Summarily, the percent of non-residual fractions extracted were $64 \% \mathrm{Ni}, 63 \% \mathrm{Cu} / \mathrm{Cd}, 65 \% \mathrm{Zn}$ and $53 \%$ $\mathrm{Pb}$. Copper was the most abundant metal in the organic matter fraction, while $\mathrm{Pb}$ was most abundant in the residual fraction.

\section{Citric acid-washed soil}

Apparently, significantly high degrees of decontamination were achieved by batch washing of soil with CA. For example, pseudototal metal contents in the washed soils (Table 5) were lowered considerably relative to the unwashed soil. In terms of fractionation patterns, it appeared that this extractant, to a great extent, targeted most of the metals hitherto associated with the exchangeable and reducible fractions, and, to a lesser extent, part of metals bound to the soil organic matter; while recording little or no effect on the redistribution of the residual metal forms. For instance, $153.50 \mathrm{mg} / \mathrm{kg} \mathrm{Ni}$ (Table 4) was found to be in association with the exchangeable and reducible forms before CA-washing but was reduced below detection limit following CAwashing. The organic matter fraction of Ni (120.30 mg/ $\mathrm{kg}$ ) recorded before $\mathrm{CA}$-washing was lowered to 110.30 $\mathrm{mg} / \mathrm{kg}$ (8\% lowering) after CA-extraction. The residual form of $\mathrm{Ni}$, however, relatively remained unextracted. About $96 \%, 68 \%$, and $59 \%$ of Cu (Fig. 2b) were extracted from the exchangeable, reducible and organic matter fractions, respectively. Almost all $\mathrm{Zn}$ present as exchangeable and organic matter forms, and up to $90 \%$ of the reducible form were extracted by CA. For Cd, CA extracted about $96 \%, 83 \%$, and $11 \%$ of the metal associated with the exchangeable, reducible and organic matter fraction. In the case of $\mathrm{Pb}, \mathrm{CA}$ completely removed the exchangeable and reducible forms, and up to about $70 \%$ of the reducible form; while enriching the residual fraction. Slight lowering in the residual fractions (2\% $\mathrm{Ni}, 6 \% \mathrm{Zn}, 8 \% \mathrm{Cu} / \mathrm{Cd}$ ) upon CA-washing were observed possibly because more metals were remobilized, hence released from this phase as the CA solution was removed and fresh extractants added during the BCR sequential extraction (Tejowulan and Hendershot, 1998). The sequential procedure was able to recover approximately $96-98 \%$ of the pseudototal metals indicating that laboratory conditions were under control. Clearly there was preponderance of the non-labile metal pools in the after CA-washing. Calculated $M_{\mathrm{f}}$ 's ranged between $0-$ $1.0 \%$ indicating reduced metal mobility, hence bioavailability. These changes in heavy metal fractionation patterns following CA-washing reflect reagent selectivity. It has been recommended that selection of suitable chelants to remove target metals from contaminated soil be based on its recoverability, effectiveness, and selectivity (Chao et al., 1998; Kabala and Singh, 2001).

\section{Tartaric acid-washed soil}

TA-washing was also found to reduce the heavy metal burdens of the contaminated soil. Pseudototal metal concentrations were significantly lowered to $163.00 \mathrm{mg} /$ $\mathrm{kg} \mathrm{Ni}, 165.00 \mathrm{mg} / \mathrm{kgCu}, 148.00 \mathrm{mg} / \mathrm{kgZn}, 149.00 \mathrm{mg} / \mathrm{kg}$ $\mathrm{Cd}$ and $169.10 \mathrm{mg} / \mathrm{kg} \mathrm{Pb}$ (Table 6). About $92-98 \%$ of pseudototal $\left(\mathrm{HNO}_{3}-\mathrm{H}_{2} \mathrm{O}_{2}\right.$-extractable) metals were recovered during $\mathrm{BCR}$ fractionation plus aqua regia extraction of residual metals. TA appeared to target the removal of the exchangeable metal pools to a great extent as can be seen from the absence of extractable metals in the $B_{1}$ fraction of BCR sequential extraction of $\mathrm{Ni}, \mathrm{Zn}$, $\mathrm{Cd}$ and $\mathrm{Pb}$ (Fig. 2c). About $13 \%$ of exchangeable $\mathrm{Cu}$ remained unextracted even after TA-washing of soil. Ke et al. (2006) also showed that sequential fractionations of treated and untreated soil samples showed that tartaric acid was effective in removing the exchangeable, carbonate fractions of $\mathrm{Cd}, \mathrm{Zn}$ and $\mathrm{Cu}$ from the contaminated soil. The contents of $\mathrm{Pb}$ and $\mathrm{Cu}$ in reducible fraction were also significantly decreased by tartaric acid treatment. In this study, apart from $\mathrm{Ni}$ for which about $67 \%$ of the reducible pool was removed, less than $10 \%$ of this fraction was removed in the case of the remaining metals. Consequently, the non-labile pools became significantly enriched in the metals. Calculated $M_{\mathrm{f}}$ 's ranged between $0-3 \%$.

\section{EDTA-washed soil}

EDTA-washing of the contaminated soil simultaneously enhanced metal extraction from the non-residual fractions and induced mineral dissolution from non-labile residual pools (Table 7; Fig. 2d).

Consequently, the heavy metal burdens of the contaminated soil were greatly lowered following 


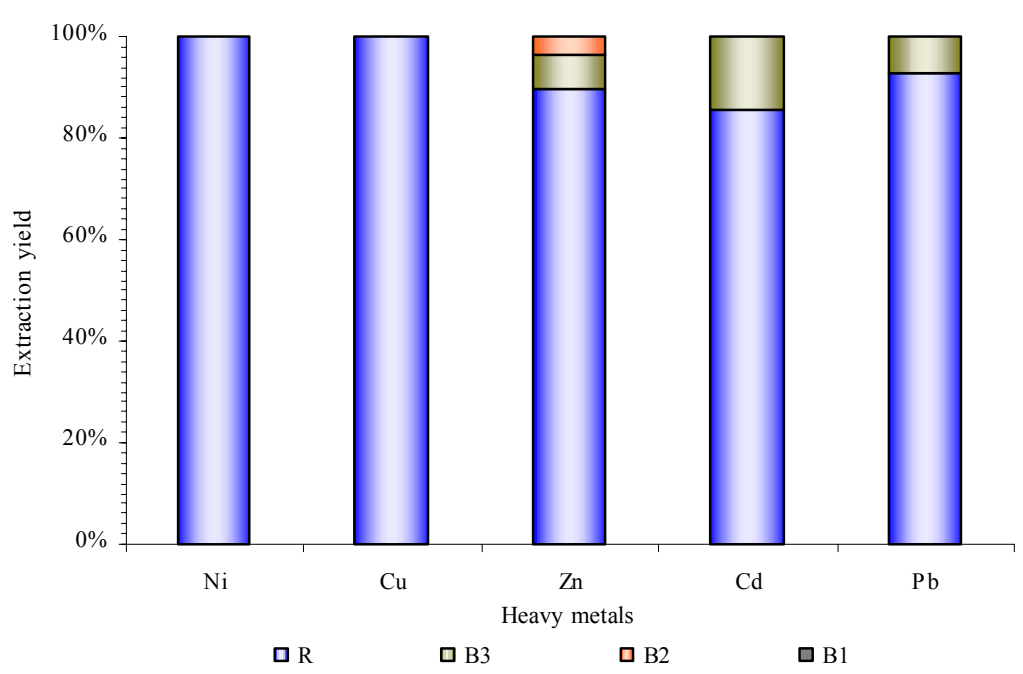

Fig. 2d: Heavy metal distribution in contaminated soil after washing with EDTA determined by the BCR sequential procedure $\left(B_{1}\right.$ $\mathrm{CH}_{3} \mathrm{COOH} ; \mathrm{B}_{2}-\mathrm{NH}_{2} \mathrm{OH}-\mathrm{HCl}$, pH1.5; $\mathrm{B}_{3}-\mathrm{H}_{2} \mathrm{O}_{2}$ then $\mathrm{CH}_{3} \mathrm{COONH}_{4}, \mathrm{pH} 2$ and $R_{4}$-aqua regia)

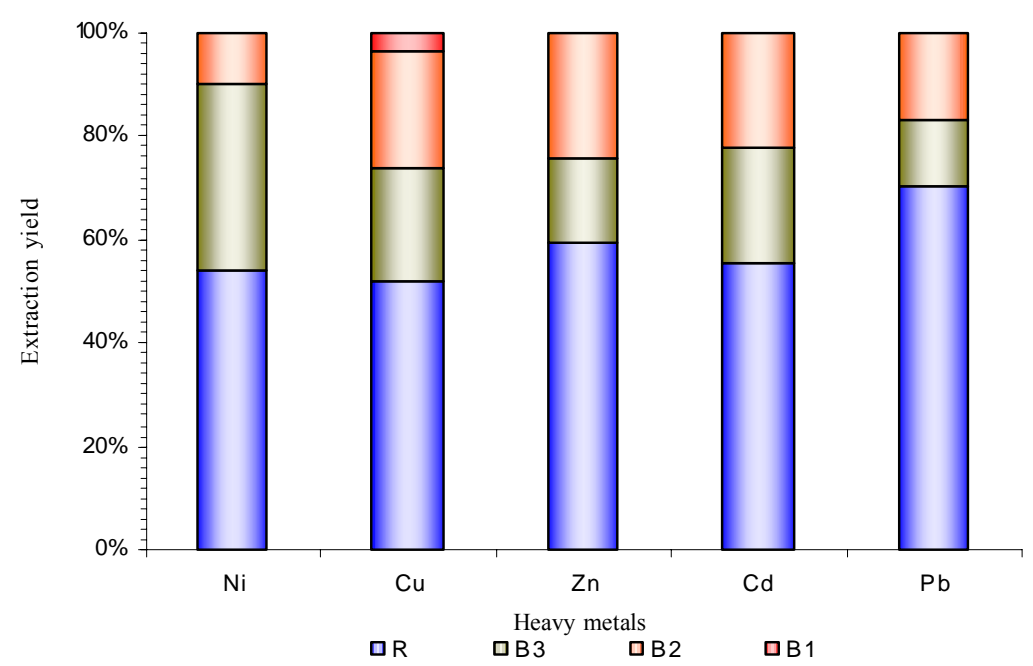

Fig. 2c: Heavy metal distribution in contaminated soil after washing with tartaric acid determined by the BCR sequential procedure $\left(B_{1}-\mathrm{CH}_{3} \mathrm{COOH} ; \mathrm{B}_{2}-\mathrm{NH}_{2} \mathrm{OH}-\mathrm{HCl}, \mathrm{pH} 1.5 ; \mathrm{B}_{3}-\mathrm{H}_{2} \mathrm{O}_{2}\right.$ then $\mathrm{CH}_{3} \mathrm{COONH}_{4}, \mathrm{pH} 2$ and $R_{4}$-aqua regia)

EDTA-washing viz: $164.00 \mathrm{mg} / \mathrm{kg} \mathrm{Ni}, 180.00 \mathrm{mg} / \mathrm{kgCu}$, $150.50 \mathrm{mg} / \mathrm{kgZn}, 145.00 \mathrm{mg} / \mathrm{kgCd}$ and $140.50 \mathrm{mg} / \mathrm{kgPb}$. $\mathrm{BCR}$ fractionation plus aqua regia extraction of residual metal pools recovered between $96-100 \%$ of these pseudototal amounts. Extractable $\mathrm{Ni}$ and $\mathrm{Cu}$ were not detected in the first three fraction of BCR sequential extraction of the EDTA-washed soil, implying that all the non-residual metal pools were removed. This observation corroborates the strong affinity of $\mathrm{Cu}$ and $\mathrm{Ni}$ towards complexation with EDTA as can be seen from their conditional stability constants. Exchangeable and reducible $\mathrm{Cd}$ and $\mathrm{Pb}$ were not detected in the first two fractions of BCR extraction exchangeable, while $\mathrm{Zn}$ was not detected in the exchangeable fraction. The residual metal pools became enriched following EDTA decontamination.

Effect of soil washing on heavy metal uptake by maize

Heavy metal concentrations $(\mathrm{mg} / \mathrm{kg})$ and metal transfer coefficients in harvested maize biomass after 35 days of growth in soil were lowered after washing with CA, TA and EDTA(Table!). In the unwashed soil, 
maize biomass metal concentrations $(\mathrm{mg} / \mathrm{kg})$ were: $\mathrm{Ni}$ (62.00), $\mathrm{Cu}$ (75.30), $\mathrm{Zn}$ (85.00), $\mathrm{Cd}$ (60.00) and $\mathrm{Pb}$ (35.90). Transfer coefficients to maize, $T_{c}$ (Fig. 3) ranged between $0.12-0.23$ and varied in the sequence: $\mathrm{Pb}<\mathrm{Ni}<\mathrm{Zn}<$ $\mathrm{Cd}<\mathrm{Cu}$. Citric acid- and TA-washing gave comparable ranges of $T_{c}(0.02-0.04$ and $0.02-0.05$, respectively), while following the sequence: $\mathrm{Pb}<\mathrm{Ni} \mathrm{H}^{\prime} \mathrm{Zn} \mathrm{H}$ " $\mathrm{Cd}<$ $\mathrm{Cu}$. This meant that $\mathrm{Pb}$ showed the least, $\mathrm{Ni} / \mathrm{Zn} / \mathrm{Cd}$ intermediate, and $\mathrm{Cu}$, the highest transferabilities to maize. After EDTA-washing, the values of $T_{c}$ were of the order $10^{-3}-10^{-2}$ and followed the sequence Ni H" $\mathrm{Pb}<\mathrm{Cu} \mathrm{H}$ " Zn H" Cd. This implied that, EDTA washed most of the plant available pool of metals. Generally, low metal transfer coefficients were observed in the washed soils implying that the chelating organic acids were effective in reducing the level of metal contaminants in the soil.

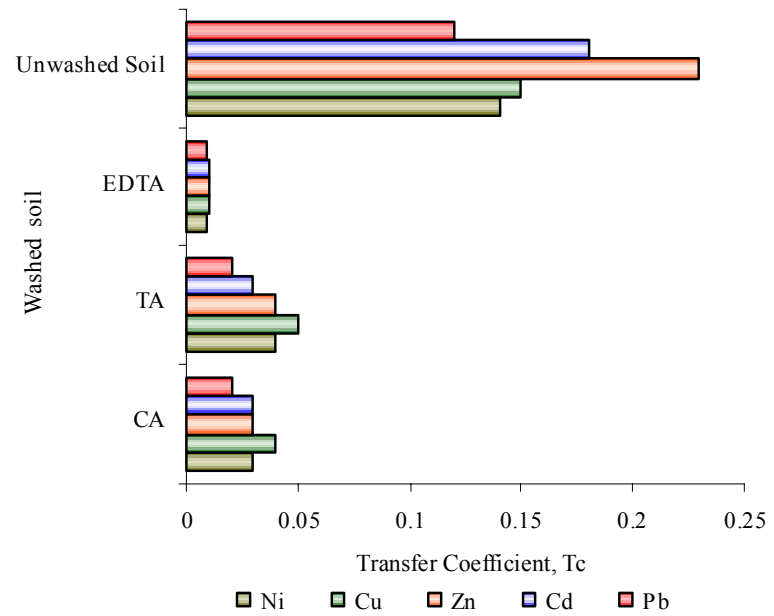

Fig. 3: Metal transfer coefficients in maize from soils spiked with quinternary mixture of heavy metals before and after decontamination by washing with various chelating agents

\section{CONCLUSION}

The study demonstrated that depending on the nature of the chelants, washing efficiencies varied in the order: EDTA $>$ citric acid $>$ tartaric acid with metal extraction yields typically following the sequence $\mathrm{Cu}$ $>\mathrm{Ni}>\mathrm{Zn}>\mathrm{Cd}>\mathrm{Pb}$. BCR sequential extractions to assess the redistribution of heavy metal forms in the soil following washing experiments showed that apparent metal mobilities, $M_{\mathrm{f}}$ were reduced upon chelant washing of soil. Citric acid appeared to remove most of the metals hitherto associated with the exchangeable and reducible fractions; tartaric acid, the exchangeable metal pools; and EDTA, all the nonresidual metal pools. Heavy metal assay of harvested biomass of maize grown on unwashed and washed soil samples indicated that metal transfer coefficients, $T_{\mathrm{c}}$ decreased in the order of treatment: EDTA $<$ citric acid $<$ tartaric acid $<$ unwashed soil. EDTA and citric acid appeared to offer greater potentials as chelating agents to use in remediating the high permeability soil. Tartaric acid, however, is recommended in events of moderate contamination.

\section{REFERENCES}

Atafar, Z. ; Mesdaghinia, A.R.; Nouri, J.; Homaee, M.; Yunesian, M.; Ahmadimoghaddam, M.; Mahvi, A. H., (2010). Effect of fertilizer application on soil heavy metal concentration. Environ. Monitor. Assess., 160 (1-4), 83-89 (7 pages).

Battaglia, A.; Calace, N.; Nardi, E.; Petronio, B.M.; Pietroletti, M., (2006). Reduction of $\mathrm{Pb}$ and $\mathrm{Zn}$ bioavailable forms in metal polluted soils due to paper mill sludge addition:Effects on $\mathrm{Pb}$ and $\mathrm{Zn}$ transferability to barley. Bioresour. Tech., 98 (16), 2993-2999 (7 pages).

Chao, J. C.; Hong, A.; Okey, R. W.; Peters, R. W., (1998). Selection of chelating agents for remediation of radionuclide-contaminated soil. Proceedings of the 1998 Conference on Hazardous Waste Research, 142-155.

Chu, W.; Chan, K. H., (2003). The mechanism of the surfactant-aided soil washing system for hydrophobic and partial hydrophobic organics. Sci. Total Environ., 307 (13), 83-92 (10 pages).

D'amore, J. J.; Al-abed, S. R.; Scheckel, K. G.; Ryan, J. A., (2005). Methods of speciation of metals in soils. J. Environ. Qual., 34 (5), 1707-1745 (38 pages).

Davies, A. P.; Singh, I., (1995). Washing of zinc ( $\mathrm{Zn}$ ) from contaminated soil column. J. Environ. Eng., 121 (2), 174185 (12 pages).

Dikinya, O.; Areola, O., (2010). Comparative analysis of heavy metal concentration in secondary treated wastewater irrigated soils cultivated by different crops. Int. J. Environ. Sci. Tech., 7 (2), 337-346 (10 pages).

Doumett, S.; Lamperi, L.; Checchini, L.; Azzarello, E.; Mugnai, S.; Mancuso, S.; Petruzzelli, G.; Del Bubba, M., (2008). Heavy metal distribution between contaminated soil and Paulownia tomentosa, in a pilot-scale assisted phytoremediation study: Influence of different complexing agents. Chemosphere, 72 (10), 1481-1490 (10 pages).

Ehsan, S.; Prasher, S. O.; Marshall, W. D., (2006). A washing procedure to mobilize mixed contaminants from soil: II. Heavy metals. J. Environ. Qual., 35 (6), 2084-2091 (8 pages).

Fawzy, E. M., (2008). Soil remediation using in-situ immobilization techniques. Chem. Eco., 24 (2), 147-156 (10 pages).

Gao, Y.; He, J.; Ling, W.; Hu, H.; Liu, F., (2003). Effects of organic acids on copper and cadmium desorption from contaminated soils. Environ. Int., 29 (5), 613-618 (6 pages). 
GOC, (2003) Site Remediation Technologies: A Reference Manual, Contaminated Sites Working Group, Ontario, Chapter 6.

Golia, E. E.; Tsiropoulos, N. G.; Dimirkou, A.; Mitsios, I., (2007). Distribution of heavy metals of agricultural soils of central Greece using the modified BCR sequential extraction method. Int. J. Environ. Anal. Chem., 87 (1314), 1053-1063 (11 pages).

Kabala, C.; Singh, B. R., (2001). Fractionation and mobility of copper, lead and zinc in soil profiles in the vicinity of a copper smelter. J. Environ. Qual, 30 (2), 485-492 (8 pages).

Ke, X.; Li, P.; Zhou, Q.; Zhang, Y.; Sun, T., (2006). Removal of heavy metals from a contaminated soil using tartaric acid. J. Environ. Sci. (China), 18 (4), 727-733 (7 pages).

Khodadoust, A. P.; Reddy, K. R.; Maturi, K., (2005). Effect of different extraction agents on metal and organic contaminant removal from a field soil. J. Hazard. Mater., 117 (1), 15-24 (10 pages).

Kirpichtchikova, T. A.; Manceau, A.; Spadini, L; Panfili, F.; Marcus, M. A.; Jacquet, T., (2006). Speciation and solubility of heavy metals in contaminated soil using Xray microfluorescence, EXAFS spectroscopy, chemical extraction, and thermodynamic modeling. Geochim. Cosmochim. Acta, 70 (9), 2163-2190 (28 pages)

Kord B.; Mataji A.; Babaie S., (2010). Pine (Pinus eldarica Medw.) needles as indicator for heavy metals pollution. Int. J. Environ. Sci. Tech., 7 (1), 79-84 (6 pages).

Labanowski, J.; Monna, F.; Bermond, A.; Cambier, P.; Fernandez, C.; Lamy, I.; van Oort, F., (2008). Kinetic extractions to assess mobilization of $\mathrm{Zn}, \mathrm{Pb}, \mathrm{Cu}$, and $\mathrm{Cd}$ in a metal-contaminated soil: EDTA vs citrate. Environ. Pollut., 152 (3), 693-701 (9 pages).

Maturi, K.; Reddy, K. R., (2008). Extractants for the removal of mixed contaminants from soils. Soil Sed. Contamin., 17 (6), 586-608 (23 pages).

Naidu, R.; Harter, R. D., (1998). Effect of different organic ligands on cadmium sorption and extractability from soils. Soil Sc. Soc. Am. J., 62 (3), 644-650 (7 pages).

Nolan, A. L.; Zhang, H.; McLaughlin, M. J., (2005). Prediction of zinc, cadmium, lead and copper availability to wheat in contaminated soils using chemical speciation, diffusive gradients in thin films, extraction and isotopic dilution techniques. J. Environ. Qual., 34 (2), 496-507 (12 pages).

Norvell, W. A., (1991). Reactions of metal chelates in soils and nutrient solutions. Mortverdt, J. J., Cox, F. R., Shuman, L. M., Welch, R. M. (Eds.), Micronutrients in Agriculture (2 ${ }^{\text {nd. }}$ Ed.), Soil Science Society of America, Wiscosin.

Nouri, J., (1980). Heavy metals in sewage sludge, soils amended with sludge and their uptake by plants. Ph.D. dissertation, Westfield College, University of London.

Nouri, J.; Mahvi, A. H.; Babaei, A.; Ahmadpour, E., (2006). Regional pattern distribution of groundwater fluoride in the Shush aquifer of Khuzestan County Iran. Fluoride, 39 (4), 321-325 (5 pages).

Nouri, J.; Khorasani, N.; Lorestani, B.; Karami, M.; Hassani, A.H.; Yousefi, N. (2009). Accumulation of heavy metals in soil and uptake by plant species with phytoremediation potential. Environ. Earth Sci., 59 (2), 315-323 (9 pages).
Nouri, J.; Mahvi, A.H.; Jahed, G.R.; Babaei, A.A. (2008). Regional distribution pattern of groundwater heavy metals resulting from agricultural activities. Environ. Geo., 55 (6), 1337-1343 (7 pages).

Nwachukwu, M. A.; Feng, H.; Alinnor, J., (2010). Assessment of heavy metal pollution in soil and their implications within and around mechanic villages. Int. J. Environ. Sci. Tech., 7 (2), 347-358 (12 pages).

Nwuche, C. O.; Ugoji, E. O., (2008). Effects of heavy metal pollution on the soil microbial activity. Int. J. Environ. Sci. Tech., 5 (3), 409-414 (6 pages).

Okezie, C.N., (1985). Geological Map of Nigeria. Div. Geological Survey, Lagos, Nigeria.

Peters, R. W., (1999). Chelant extraction of heavy metals from contaminated soils. J. Hazard. Mater., 66 (2), 151 210 (60 pages).

Reddy, K. R.; Chinthamreddy, S., (2000). Comparison of extractants for removing heavy metals from contaminated clayey soils. Soil Sediment Contaminat., 9 (5), 449-462 (14 pages).

Soil Survey Staff, (1998). Keys to Soil Taxonomy ( $8^{\text {th. }}$ Ed.), USDA-NRCS, Center Technology Evaluation Report TE98-01, 37

Sun, B.; Zhao, F. J.; Lombi, E.; McGrath, S. P., (2001). Leaching of heavy metals from contaminated soils using EDTA. Environ. Pollut., 113 (2), 111-120 (10 pages).

Tejowulan, R. S.; Hendershot, W. H., (1998). Removal of trace metals from contaminated soils using EDTA incorporating resin trapping techniques. Environ. Pollut., 103 (1), 135-142 (8 pages).

Tokalioglu, S.; Kartal, S.; Gültekin, A., (2006). Investigation of heavy-metal uptake by vegetables growing in contaminated soils using the modified BCR sequential extraction method. Int. J. Environ. Anal. Chem., 86 (6), 417-430 (14 pages).

Ure, A. M.; Quevauviller, P. H.; Muntau, H.; Griepink, B., (1993). Speciation of heavy metals in soils and sediments. An account of the improvement and harmonization of extraction techniques undertaken under the auspices of the BCR of Commission of the European Communities. Int. J. Environ. Anal. Chem., 51 (1-4), 135-151 (17 pages).

USEPA (1990). Engineering bulletin: Soil washing treatment, EPA/540/2-90/017, Office of Emergency and Remedial Response, Washington, D.C.

USEPA (1995). Contaminants and remedial options at selected metal contaminated sites, EPA/542/R - 97/004, Office of Research and Development, Washington, D.C.

Wood, A. L.; Bouchard, D. C.; Brusseau, M. L.; Rao, S. C., (1990). Cosolvent effect on sorption and mobility of organic contaminants in soils. Chemosphere, 21 (4-5), 575-587 (13 pages).

Wood, P., (1997). Remediation Methods for Contaminated Sites, in: Hester, R. and Harrison, R. (Eds.), Contaminated Land and Its Reclamation, Royal Society of Chemistry, Cambridge.

Yu, J.; Klarup, D., (1994). Extraction kinetics of copper, zinc, iron, and manganese from contaminated sediment using disodium Ethylenediaminetetraacetate. Water Air Soil Pollut., 75 (3 - 4), 205-225 (21 pages). 
Zhang, H.; Zheng, L.C.; Yi, X.Y., (2009). Remediation of soil co-contaminated with pyrene and cadmium by growing maize (Zea mays L). Int. J. Environ. Sci. Tech., 6 (2), 249-258 (10 pages).
Zvinowanda, C. M.; Okonkwo, J. O.; Shabalala, P. N.; Agyei, N. M., (2009). A novel adsorbent for heavy metal remediation in aqueous environments. Int. J. Environ. Sci. Tech., 6 (3), 425-434 (10 pages).

\section{AUTHOR (S) BIOSKETCHE}

Wuana, R. A., M.Sc., Lecturer, Department of Chemistry, Benue State University, Makurdi, Nigeria. His Doctoral thesis is currently awaiting defence at the University of Benin, Benin City, Nigeria.

Email: raywuana@yahoo.com

Okieimen, F. E., Ph.D., Full Professor, Department of Chemistry, University of Benin, Benin City, Nigeria.

Email:fexokieimen@yahoo.com

Imborvungu, J. A., B.Sc., Benue State University, Makurdi, Nigeria

Email: jack428@yahoo.com

How to cite this article: (Harvard style)

Wuana, R. A.; Okieimen, F. E.; Imborvungu, J. A., (2010). Removal of heavy metals from a contaminated soil using chelating organic acids. Int. J. Environ. Sci. Tech., 7 (3), 485-496. 